\title{
ITERATIVE APPROXIMATIONS FOR A FAMILY OF MULTIVALUED MAPPINGS IN BANACH SPACES
}

\begin{abstract}
ZHANFEI ZUO
Abstract. In this paper we consider the convergence of iterative processes for a family of multivalued nonexpansive mappings. Under somewhat different conditions the sequences of Noor, Mann and Ishikawa iterates converge to the common fixed point of the family of multivalued nonexpansive mappings.
\end{abstract}

Mathematics subject classification (2010): 47H09, 47H10, 47H15..

Keywords and phrases: Multivalued nonexpansive mapping; convergence theorems; fixed points.

\section{REFERENCES}

[1] N. A. ASSAD AND W. A. KIRK, Fixed point theorems for set-valued mappings of contractive type, Pacific J. Math, 43 (1972), 553-562.

[2] D. DowIng AND W. A. KIRK, Fixed point theorems for set-valued mappings in metric and Banach spaces, Math. Japonicae, 22 (1977), 99-112.

[3] S. IshikaWA, Fixed points by a new iteration method, Proc. Amer. Math. Soc. 44 (1974), 147-150.

[4] W. A. KIRK, Transfinite methods in metric fixed point theory, Abstract and Applied Analysis, 5 (2003), 311-324.

[5] T. C. LIM, A fixed point theorem for multivalued nonexpansive mappings in a uniformly convex Banach space, Bull. Amer. Math. Soc, 80 (1974), 1123-1126.

[6] T. C. LiM, Remarks on some fixed point theorems, Proc. Amer. Math. Soc, 60 (1976), 179-182.

[7] W. R. MAnN, Mean value methods in iteration, Proc. Amer. Math. Soc, 4 (1953), 506-510.

[8] S. B. NAdLeR JR, Multi-valued contraction mappings, Pacific J. Math. 30 (1969), 475-487.

[9] W. Nilsrakoo, S. SAEJUng, A new three-step fixed point iteration scheme for asymptotically nonexpansive mappings, Appl. Math.Comput. 181 (2006) 1026-1034.

[10] W. NilsRakoo, S. SAEJUnG, A reconsideration on convergence of Three-step iterations for asymptotically nonexpansive mappings, Appl. Math. Comput. 190 (2007), 1472-1478.

[11] M. A. Noor, New approximation schemes for general variational inequalities, J. Math. Anal. Appl. 152 (2000), 217-229.

[12] M. A. Noor, Some developments in general variational inequalities, Appl. Math. Comput. 152 (2004), 199-277.

[13] M. A. NOOR AND Y. YAO, Three-step iterations for variational inequalities and nonexpansive mappings, Appl. Math. Comput. 190 (2007) 1312-1321.

[14] Z. OPIAL, Weak convergence of the sequence of successive approximations for nonexpansive mappings, Bull. Amer. Math. Soc, 73 (1967), 591-597.

[15] B. PANYANAK, Mann and Ishikawa iterative processes for multivalued mappings in Banach spaces, Computers and Mathematics with Applications, 54 (2007), 872-877.

[16] D. R. SAHU, Strong convergence theorems for nonexpansive type and non-self multi-valued mappings, Nonlinear Anal, 37 (1999), 401-407.

[17] K. P. R. SASTRY, G. V. R. BABU, Convergence of Ishikawa itreates for a multi-valued mapping with a fixed point, Czechoslovak Math. J, 55 (2005) 817-826.

[18] H.F. Senter And W.G. Dotson, Approximating fixed points of nonexpansive mappings, Proc. Amer. Math. Soc. 44 (1974), 375-380. 
[19] Y. S. Song AND H. J. WANG, Convergence of iterative algorithms for multivalued mappings in Banach spaces, Nonlinear Anal, 70 (2009) 1547-1556.

[20] T. SUZUKI, Strong convergence theorems for infinite families of nonexpansive mappings in general Banach spaces, Fixed Point Theory Appl. 1 (2005), 103-123.

[21] H. K. XU, Inequalities in Banach spaces with applications, Nolinear Anal. 16 (1991), 1127-1138.

[22] M. ZHU, Convergence of iterative algorithms for multivalued mapping and fixed point, Dissertation for the Master Degree in Science, Hubei University in China, 2001.5. 